\title{
The Free Senior High Policy: An Appropriate Replacement to The Progressive Free Senior High Policy
}

\author{
Nurudeen Abdul-Rahaman ${ }^{1 *}$, Abdul Basit Abdul Rahaman², Wan Ming ${ }^{1}$, Abdul-Rahim Ahmed ${ }^{1}$, Abdul-Rahaman S. Salma ${ }^{1}$ \\ ${ }^{1}$ University of Science and Technology of China \\ ${ }^{2}$ Ghana Education Service, Ghana
}

Corresponding author: Nurudeen Abdul-Rahaman, E-mail: nurudeenkuberke@gmail.com

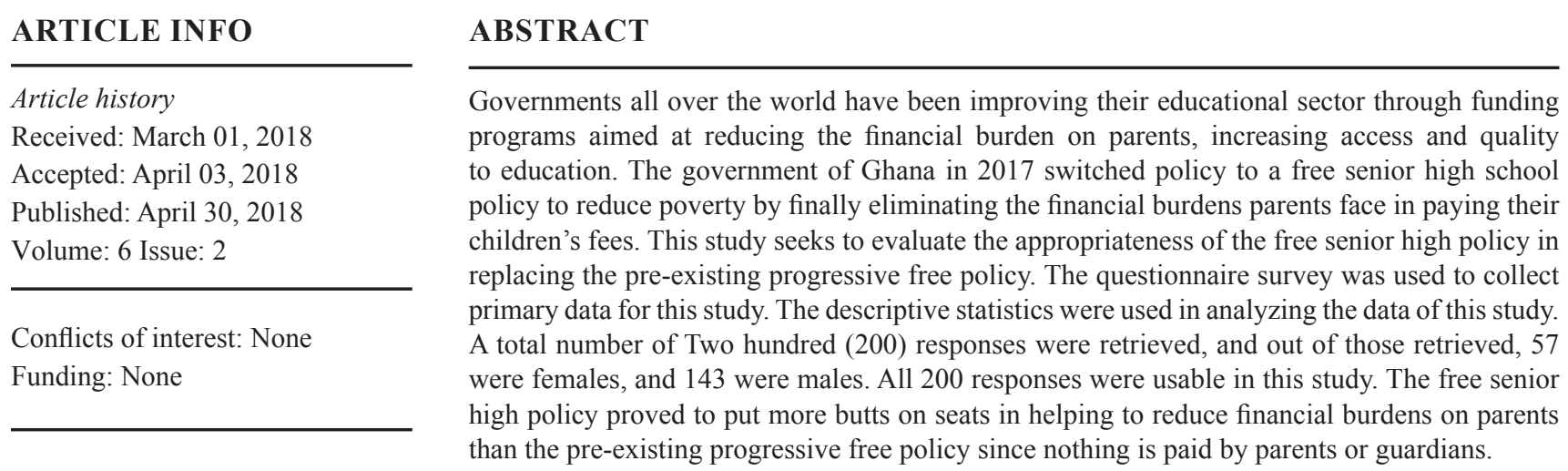

Key words: Free Senior High Policy, Government Funding, Progressive Free Senior High Policy, Poverty

\section{INTRODUCTION}

"Sustained poverty reduction requires a commitment to reduce inequality and improve access to opportunities for all citizens" (World Bank, 2015). Ghana's rural development and urbanization have led to a significant poverty reduction in the southern part of the country. However, the rate of poverty is still very high in northern Ghana. Between 1992 and 2006, the number of poor people decreased by 2.5 million in the southern part and increased by 900,000 in the Northern, Upper East, and Upper West regions of Ghana. Poverty remains endemic in the northern areas of the country, with the poverty rate standing at 87.9 percent for Upper West in 2006. The Upper West was the poorest among the ten regions of Ghana, where the rate of poverty shot up from $38.8 \%$ in 1999 to $48 \%$ in $2005 / 2006$ (GSS, 2007). It has led the World Bank to declare that Ghana's success story in poverty reduction is the success story of its southern parts only (World Bank 2011). In bridging the enrollment gap between the rich and poor, the government introduced the free compulsory basic education which is a constitutional requirement. It covers eleven years of universal basic education which include two years of kindergarten, six years of primary, and three years of junior high school. This objective is mostly achieved through the capitation grants and the school feeding program. Such interventions led to an increase in enrollment of pupils at an exponential rate over the years because parents do not have to pay for their children education. It has increased demand for senior high school education in the country and hence increased in pressure of family income as parents would have to pay their children's fees. As part of the government strategies to help curb down this economic pressure on parents, the free senior high school policy introduced by the newly elected government is seen by many as a step in the right direction. This free senior high policy replaced the progressive free senior high policy implemented in 2015. This progressive free senior policy was a form of partial funding to senior high education. Parents were exempted from paying some of the costs of education such as; examination fees, entertainment fees, library, Students Representative Council (SRC) dues, sports fees, culture fees, science development and mathematics quiz fees, Information and Communication Technology (ICT) fees and co-curricular fees.

The current policy on senior high school education is to provide free education. That is free tuition, no library fee, no boarding fee, no science laboratory fee, no examination fee, no utility fee, free meals for both boarders and day-students, no Parents Teachers Association (PTA) fee, and free textbooks for all at the senior high level. Both policies aimed to increase enrollment, improve quality through academic performance and most importantly to reduce the burden on parents from paying their children fees.

Published by Australian International Academic Centre PTY.LTD.

Copyright (c) the author(s). This is an open access article under CC BY license (https://creativecommons.org/licenses/by/4.0/)

http://dx.doi.org/10.7575/aiac.ijels.v.6n.2p.26 
There are several studies conducted on the impact of funding on enrollment and students' academic performance. For instance, the Free education introduced in South Africa in some areas enabled poor parents to enroll their children in school (Boatman \& Long, 2016; Blanco \& Meneses, 2010; Dynarski \& Scott-Clayton, 2013; Garlick, 2013; Melguizo, 2011 and Taryn \& Claudia M. 2012). Other studies also found funding to be useful in improving the academic performance of students. These studies are Denny et al. (2014) Moussa et al. 2015 Natasha et al. (2011) Stater (2009) Tatiana et al. (2016).

Looking at what has been done in the past, this study takes a step further to evaluate the new education policy against the pre-existing progressive free senior high education policy in regards to poverty alleviation among parents and quality of education in the Wa Municipality of Ghana.

This study would evaluate the two policies based on what parents or guardians say and not what politicians say because parents are the direct beneficiaries of the economic impact of the two policies.

\section{Objective}

- $\quad$ Evaluate the effectiveness of the free senior high policy which replaced the progressive free senior high policy in reducing poverty in the Wa Municipality of Ghana.

\section{Research Question}

- Is the free senior high policy an appropriate replacement to the progressive free senior high policy in reducing poverty in the Wa Municipality of Ghana?

\section{The Senior High School System in Ghana}

The educational system in Ghana follows a 6-3-3-4 system. Senior high school education covers three years for students aged 15 to 17 years. There are 863 (562 public and private 301) senior high schools which cater for the needs of 837,204 students. There are 34,304 teachers in public senior high schools of which $86.7 \%$ are trained. The sub-program has an in-service training program for teachers to ensure that they have up-to-date knowledge of the curriculum and related teaching and learning materials (MOE, 2016).

Subjects taught in the senior high schools are English, Integrated Science, Mathematics and Social studies as core subjects and students are required to select a group of elective subjects from seven elective groupings of subjects.

It is this level of education that is currently being offered for free and had been previously progressively free before September 2017.

\section{LITERATURE REVIEW}

The literature of the study is reviewed according to themes. These themes are, the empirical evidence of the study detailing the significance of funding in reducing the burden on parents paying fees. There is some evidence from previous studies relating the effect of funding to schools on parents or guardians. Most of these studies showed a positive relationship between funding and poverty alleviation. For instance,

Joseph, Laura, Peter and Jonathan (2000) after carrying out research, suggested that the American government and other institutions can relieve burdens on families by promoting saving and reducing the cost of college attendance through expanded financial aid.

Similarly, in 2015, more than 300 students from different private colleges were asked to talk about the impact of the US State Grant program, and this is what one of the students said "My family is low-income and I am the first-generation student. It is difficult for my family to understand the support I need to obtain a four-year degree. Without the State Grant, I would not be going to St Olaf. I would probably be working an ordinary job and not pursuing a college career" (Zoula Lor, 2015).

According to Todora and Smith (2006), "Widespread abject poverty creates conditions in which the poor have no access to credit, are unable to finance their children's education, and, in the absence of physical or monetary investment opportunities, have many children as a source of old-age financial security". In the same vein Obeng (2012) declares:

Cost of education has been identified to constitute a significant proportion of the income of most people in Ghana whose daily lives are visited by abject poverty. Taking giant steps to bring economic recovery to its citizens through education, the Government of Ghana has taken the burden off parents through the implementation of the capitation grant policy. (p. 2)

The introduction of free primary education led to the poor enrolling their children in schools in Uganda (Deininger, 2003). Also, in a later study, Olwande et al. (2010) assessed the effect of Free Primary Education in rural Kenya applying panel data from about 1500 households between 2000 and 2007, to check the enrollment trends. They found out that parents could enroll their students in school because of the implementation of Free Primary Education.

Another study indicated that children from high-income families perform better than children from needy families in areas such as communication skills, knowledge of numbers, ability to concentrate and in playing with other children in a cooperative manner (Thomas, 2007).

A study carried out by Janus et al. (2007) found that schools with the highest number of children with low school readiness were from areas of high social risk and poverty. In line with this, Willms (2007) stated that

children from lower socioeconomic status (SES) households scored lower on a receptive vocabulary test than higher SES children. Thus, the evidence is clear and unanimous that poor children arrive at school at a cognitive and behavioral disadvantage. Schools are obviously not in a position to equalize this gap. For instance, research by The Institute of Research and Public Policy (Montreal, Quebec) showed that differences between students from low and high socioeconomic neighborhoods were evident by grade 3 ; children from low socioeconomic neighborhoods were less likely to pass a grade 3 standards test. 
Finally, Akyeampong (2009) argued that funding for senior high school education is necessary to make it easier for people from needy families to participate in education and in reducing the financial burden on parents.

\section{Source of Funding to Senior High Schools}

Garcia-Penalosa and Wald (2000) are of the view that, acquiring literacy and numeracy is a fundamental human requirement and Pettinger (2012) who argued that educating individual benefits the society more than the individual as it equips a person with social values that enhance national unity.

The heightened demand for secondary education is accompanied by the need to respond to the twin challenges of increasing access to and also, improving quality and significance of secondary education. It, therefore, calls for more efficient sources of funding secondary education (World Bank, 2013). These arguments, therefore, makes it justifiable for the financing of senior high education.

In all countries worldwide, a significant portion of national resources, both public and private, are channeled to education. The rationale for sustaining this fact is compelling. A quality education, beginning with primary education, is fundamental in endowing individuals with the capacity to successfully pursue their private goals. It also equips them with the knowledge and skills, as well as the values and attitudes, necessary to contribute effectively to the economic, social and political development of their societies (Saavedra, 2002).

Education in Ghana is mainly financed from public resources, even though the private sector is also playing an important role. Public sources of funding comprise The Ghana Education Trust Fund, the District Assemblies Common Fund (DACF), the Ministry of Education, youth and sports (MOEYS), the Student Loan Scheme, and the Scholarship Secretariat (African Development Fund, 2003).

The internally generated funds and loans, grants and donations the government of Ghana gets were used in subsidizing the cost of senior high education to improve equal access for all. The Government of Ghana launched the progressively free senior high School Education in September 2015, and an amount of $\mathrm{GH} \notin 12,178,544.00(\$ 2,744334)$ was released to the ministry of Education for the first term of 2015/2016 academic year to fund the progressive free policy (MOE, 2015). The free senior high school education policy pursued currently is supposed to cover the full cost of education. An amount $\$ 100$ million ( $\mathrm{GH} \notin 400$ million) by the government was to absorb the cost of senior high education and make it entirely free for the 2017/2018 academic year (MOE, 2017).

The government of Ghana and the World Bank Group signed a \$156 million financing agreement to improve equal access to secondary education in under-served districts throughout the country. The fund was to help enroll 30,000 new senior high students, improve learning outcomes for 150,000 students in low-performing schools and communities, and 2000 senior high school teachers, head teachers, and other education officials (World Bank, 2014).

Since the establishment of the Skills Development Fund (SDF) in 2010, the Danish government has been consistently supporting Ghana with $\$ 15$ million every year to give more people access to technical and vocational training MOE (2017).

$\mathrm{GoG}=$ government of Ghana, $\mathrm{IGF}=$ internal generated fund, GET fund= Ghana education trust fund, highly indebted poor country, MDRI= multi-lateral debt relief initiative. Table 1 shows the sources of funding to Senior High Education in Ghana.

\section{METHOD}

The objective of this paper is to evaluate the free senior high school education policy currently being pursued in Ghana as an appropriate replacement for the previous progressively free policy in the Wa Municipality of Ghana. The Wa Municipality is located in the upper west region of Ghana. There are six (6) senior high schools and out of these six schools, five schools are public senior high schools.

\section{Sample}

Out of six (6) senior high schools in the Wa Municipality, five schools were targeted in this study because they are public schools and beneficiaries to government funding. Fifty (50) students were sampled in each school in all levels and were asked to give questionnaires to their parents. The students were taken from all classes at senior high schools because students in classes 2 and 3 benefited from progressive free high school policy while those in class 1 benefited from the free senior high policy.

\section{Instrument}

The study applied the qualitative method to examine the views of parents, and the questionnaire survey was used in collecting data for this study. Two hundred and fifty (250) questionnaires were given to students from five (5) public senior high schools to be filled by their parents. Students whose parents were illiterates were asked to read questions to their parents and guide them to respond. Parents or guardians' signatures or thumbprints were required on each questionnaire with dates and telephone numbers to ensure the credibility of each response. The Likert scale with five levels was used: strongly agree, agree, uncertain, strongly disagree, disagree, coded as 5 to 1 , respectively.

\section{Data Analysis}

A total number of 200 responses were retrieved, and out of those retrieved, 57 were females, and 143 were males. All the 200 responses were usable and analyzed using the descriptive statistics. The targeted respondents were parents because they are those who pay fees and benefit from the progressive free and free senior high policies. The Statistical Package for Social Science (SPSS) software was used as software in the data analysis.

\section{RESULTS}

A total number of two hundred (200) questionnaires were retrieved, 57 of the valid questionnaires were females rep- 
resenting $28.5 \%$, and 143 were males representing $71.5 \%$ which is indicated in Table 3. The reason for more males is because of the assumption that, men are the breadwinners of the family. Table 2 describes the age of two-hundred (200) parents or guardians who were contacted during the survey.

It revealed that the mean age is forty-nine (49) years with a standard error of 0.89829 . The minimum and maximum ages of parent or guardian are twenty-three (23) and eightysix (86) respectively. Table 3 reveals that only $1 \%$ and $3.5 \%$ of parents or guardians respectively disagree and strongly disagree that education brings about individual and societal growth with $2.5 \%$ uncertain of the prospects of education.

However, with $34 \%$ of parents or guardians agreeing that education is the key to development, more than $50 \%$ of the population is of the firm conviction that education propels individual and societal growth and development. The table indicates that majority of parents or guardians strongly agreed that education is the key to progress and thus have realized education is necessarily an important vehicle to bring positive change to individuals and society in general.

It is not surprising to see that more than $60 \%$ of parents or guardians strongly agreed that education determines the future direction of an individual as revealed in Table 3. More than $50 \%$ strongly agreed that education propels individual and societal growth and development. The table indicated that majority of parents or guardian are well enlightened that education is the surest way to growth and development. However, financial issues often bared so many pupils from enrolling into senior high school. With government intervention, a lot of parents or guardians $(30 \%)$ agreed that the financial assistance from government had cushioned them to comfortably send their wards to school without any financial stress. In contrast to the view of almost same number, $28.5 \%$ strongly disagreed to the accession that the government subsidies helped them to enroll their children into senior high school. More than $50 \%$ of parents or guardians are in one way, or another know the Progressive Free Senior High school (PFSHS) as revealed in the table. While 36\% are aware of PFSHS, $41 \%$ are firmly aware. These statistics indicate that majority of the populace are aware of PFSHS while $18.5 \%$ are either uncertain of the policy or entirely unaware of it. Under PFSHS policy, 51\% of contacted persons are paid less money for their wards SHS education than the period without PFSHS, $1 \%$ are uncertain of the impact of the program, and $47 \%$ disagreed to have paid less. Those who strongly oppose to have paid less under the policy are in a slight majority than those who agreed to have paid less. However, those with uncertainty are in a minority. Table 3 further showed that more than $70 \%$ of parents or guardians have agreed that PFSHS has improved the quality of education. Indeed, less than $30 \%$ of parents or guardians do not accept that the policy has improved the quality as well as the access to education.

Table 3 revealed that the current policy thus Free Senior High School (FSHS) has been given low publicity because about $52 \%$ of parents or guardians are unaware of FSHS while only $41.5 \%$ of parents or guardians know of the policy.

Interestingly, about $11 \%$ of the parents contacted are uncertain of the existence of FSHS. From the table, it is quite clear that majority are not aware of FSHS though its implementation.

The Free Senior High School policy (FSHS) as indicated by the government covers only the first year students that upon its implementation. However, the table showed the FSHS covers not all students (73\%), and 23\% agreed to it thus. The $23 \%$ of the people responses are not out of place as the majority of the respondents were not aware of FSHS and hence would not comprehend the pith of free senior high policy.

As to whether the Free Senior High School (FSHS) would improve quality of education and its access, $60 \%$ of respondents indicated that the policy would positively affect the quality of education. While $7 \%$ are uncertain of the policy's improving quality of education, $6.5 \%$ of them say the policy has no bearing on the quality of education. However, a majority of $26.5 \%$ of respondents strongly disagree that

Table 1. Source of government funding to senior high schools (MOE, 2015)

\begin{tabular}{lcccc}
\hline Source & $\mathbf{2 0 1 1}$ & $\mathbf{2 0 1 2}$ & $\mathbf{2 0 1 3}$ & $\mathbf{2 0 1 4}$ \\
\hline GoG & $2,563,391576$ & $4,587,183213$ & $4,503,777,590$ & $5,235,932,539$ \\
Donor & $127,255,813$ & $114,311,680$ & $268,872,043$ & $321,804,307$ \\
IGF & $354,288,649$ & $630,674,197$ & $718,265,642$ & $799,538,356$ \\
GETfund & $518,486,027$ & $361,279,228$ & $196,649,413$ & $196,649,413$ \\
HIPC/MDRI & $2,288,506$ & 0 & 0 & 0 \\
Annual budget funding amount (ABFA) & 0 & $10,571,282$ & $9,113,628$ & $10,667,891$ \\
\hline
\end{tabular}

$\mathrm{GoG}=$ government of Ghana, IGF= internal generated fund, GET fund= Ghana education trust fund, highly indebted poor country,

MDRI $=$ multi-lateral debt relief initiative.

Table 2. Descriptive statistics results for participants' ages

\begin{tabular}{|c|c|c|c|c|c|c|}
\hline & \multirow{2}{*}{$\frac{\mathrm{N}}{\text { Statistic }}$} & \multirow{2}{*}{$\begin{array}{c}\text { Minimum } \\
\text { Statistic }\end{array}$} & \multirow{2}{*}{$\begin{array}{c}\text { Maximum } \\
\text { Statistic }\end{array}$} & \multicolumn{2}{|c|}{ Mean } & \multirow{2}{*}{$\begin{array}{c}\text { Standard deviation } \\
\text { Statistic }\end{array}$} \\
\hline & & & & Statistic & Standard error & \\
\hline AGE & 200 & 23.00 & 86.00 & 49.65 & 0.898 & 12.703 \\
\hline Valid N (listwise) & 200 & & & & & \\
\hline
\end{tabular}

$\mathrm{N}=$ number, $\mathrm{std}=$ standard. 
Table 3. Descriptive statistics results for parents' responses

\begin{tabular}{|c|c|c|c|}
\hline Questions & Frequency & Percent & Cumulative ercent \\
\hline \multicolumn{4}{|c|}{ 1. Education propels individual and societal growth and development } \\
\hline Strongly agree & 117 & 58.5 & 58.5 \\
\hline Agree & 68 & 34.0 & 92.5 \\
\hline Uncertain & 5 & 2.5 & 95.0 \\
\hline Not Applicable & 1 & 0.5 & 95.5 \\
\hline Strongly disagree & 7 & 3.5 & 99.0 \\
\hline Disagree & 2 & 1.0 & 100 \\
\hline \multicolumn{4}{|c|}{ 2. Senior high school education determines an individual future direction } \\
\hline Strongly agree & 132 & 66.0 & 66.0 \\
\hline Agree & 58 & 29.0 & 95.0 \\
\hline Not applicable & 1 & 0.5 & 95.5 \\
\hline Strongly disagree & 5 & 2.5 & 98.0 \\
\hline Disagree & 4 & 2.0 & 100 \\
\hline \multicolumn{4}{|c|}{$\begin{array}{l}\text { 3. Without government funding my child could not enroll into senior high } \\
\text { school }\end{array}$} \\
\hline Strongly agree & 46 & 23.0 & 23.0 \\
\hline Agree & 60 & 30.0 & 53.0 \\
\hline Uncertain & 8 & 4.0 & 57.0 \\
\hline Not applicable & 1 & 0.5 & 57.5 \\
\hline Strongly disagree & 57 & 28.5 & 86.0 \\
\hline Disagree & 28 & 14.0 & 100 \\
\hline \multicolumn{4}{|c|}{ 4. Aware of progressive free SHS policy } \\
\hline Strongly agree & 82 & 41.0 & 41.0 \\
\hline Agree & 72 & 36.0 & 77.0 \\
\hline Uncertain & 21 & 10.5 & 87.5 \\
\hline Not applicable & 7 & 3.5 & 91.0 \\
\hline Strongly disagree & 9 & 4.5 & 95.5 \\
\hline Disagree & 9 & 4.5 & 100 \\
\hline \multicolumn{4}{|c|}{ 5. Under the progressive SHS policy, I paid less for my child } \\
\hline Strongly agree & 62 & 31.0 & 31.0 \\
\hline Agree & 42 & 21.0 & 52.0 \\
\hline Uncertain & 2 & 1.0 & 53.0 \\
\hline Not applicable & 8 & 4.0 & 57.0 \\
\hline Strongly disagree & 46 & 23.0 & 80.0 \\
\hline Disagree & 40 & 20.0 & 100 \\
\hline \multicolumn{4}{|c|}{$\begin{array}{l}\text { 6. The progressive senior high policy has improved the quality and access to } \\
\text { senior high education }\end{array}$} \\
\hline Strongly agree & 81 & 40.5 & 40.5 \\
\hline Agree & 75 & 37.5 & 78.0 \\
\hline Uncertain & 17 & 8.5 & 86.5 \\
\hline Not applicable & 6 & 3.0 & 89.5 \\
\hline Strongly disagree & 7 & 3.5 & 93.0 \\
\hline Disagree & 14 & 7.0 & 100 \\
\hline \multicolumn{4}{|c|}{ 7. I am aware of the free senior high school policy } \\
\hline Strongly agree & 47 & 23.5 & 23.5 \\
\hline Agree & 36 & 18.0 & 41.5 \\
\hline Uncertain & 22 & 11.0 & 52.5 \\
\hline
\end{tabular}


Table 3. (Continued)

\begin{tabular}{|c|c|c|c|}
\hline Questions & Frequency & Percent & Cumulative ercent \\
\hline Not Applicable & 6 & 3.0 & 55.5 \\
\hline Strongly disagree & 54 & 27.0 & 82.5 \\
\hline Disagree & 35 & 17.5 & 100 \\
\hline \multicolumn{4}{|c|}{ 8. The free senior high policy covers all students in senior high schools } \\
\hline Strongly disagree & 146 & 73.0 & 73.0 \\
\hline Disagree & 54 & 27.0 & 100 \\
\hline \multicolumn{4}{|c|}{ 9. The free senior high policy will improve quality of education } \\
\hline Strongly agree & 69 & 34.5 & 34.5 \\
\hline Agree & 51 & 25.5 & 60.0 \\
\hline Uncertain & 14 & 7.0 & 67.0 \\
\hline Not applicable & 13 & 6.5 & 73.5 \\
\hline Strongly disagree & 39 & 19.5 & 93.0 \\
\hline Disagree & 14 & 7.0 & 100 \\
\hline \multicolumn{4}{|c|}{$\begin{array}{l}\text { 10. I have paid some amount to enroll my child to senior high school under } \\
\text { free senior policy }\end{array}$} \\
\hline Strongly agree & 29 & 14.5 & 14.5 \\
\hline Agree & 15 & 7.5 & 22.0 \\
\hline Uncertain & 15 & 7.5 & 29.5 \\
\hline Not applicable & 8 & 4.0 & 33.5 \\
\hline Strongly disagree & 61 & 30.5 & 64.0 \\
\hline Disagree & 72 & 36.0 & 100 \\
\hline TOTAL & 200 & 100.0 & \\
\hline
\end{tabular}

the policy would improve the quality of education. Therefore, there is no denying the fact that the policy will entirely enhance the quality of education.

One of the basics of Free Senior High School (FSHS) is that no parents or guardians are expected to pay any dime for their ward to enter the senior high school which would help reduce poverty in the Municipality. However, based on our results (Table 3 ) more than $50 \%$ of parents or guardians paid no amount of money for their ward to enroll into SHS. It is surprising some insisted they had to pay some funds because some head teachers charged fees at the blind side of the government. The government must, therefore, ensure that head teachers do not charge these illegal fees to achieve its aim of reducing poverty drastically in the Wa Municipality and the nation as a whole.

\section{DISCUSSION}

The results showed that the free senior high policy is an appropriate replacement to the pre-existing progressive free policy but more needs to be done to improve the program to achieve its aim of reducing poverty among parents, improving quality and access to senior high education in the $\mathrm{Wa}$ Municipality of Ghana.

As indicated in the results, $34 \%$ of parents or guardians agreed that education is the key to development and more than $50 \%$ of the population is of the strong conviction that education propels societal growth and development. The importance of education is further emphasized by more than $60 \%$ of parents who strongly agreed that senior high education determines an individual's direction. It, therefore, ascertains the fact that investing in senior high education through any of the policies under the study has been a remarkable achievement of the government of Ghana to improve both access and quality to education and more significantly reducing poverty in the country. This corresponds to the view, a quality education, beginning with primary education, is fundamental to endow individuals with the capacity to successfully pursue their private goals. While at the same time equipping them with the knowledge and skills, as well as the values and attitudes, necessary to contribute to the economic, social and political development of their societies (Garcia-Penalosa \& Wald, 2000; Pettinger, 2012; Saavedra, 2002)

Government funding in the form of the pre-existing progressive free policy and the free senior high policy currently being enjoyed is proven to have reduced the financial difficulties parents go through in paying the children fees. It is evident in the results of this study, and thus $30 \%$ agreed that the funding from the government had cushioned them to comfortably send their wards to school without any financial stress. It would, in the long run, see to the reduction of poverty among families and the overall development of the nation since parents would pay less or nothing for their children's education. More than $28 \%$ of parents or guardians strongly disagreed to the accession that government subsidies helped them to enroll their children to senior high school and this is because they are not aware the 
government absorbed some of the cost of their children's education under the progressive free policy. Their ignorance of the policy is shown in the results which showed that $41 \%$ are firmly unaware of the progressive free policy. Children can be equipped with knowledge and skills to take up proactive roles in the society if they are given quality education at the senior high level. About $70 \%$ of parents or guardians have agreed that the progressive free policy has improved the quality of education as against less than $30 \%$ of parents or guardians who do not accept that the policy has improved the quality as well as the access to education. With the free senior high policy, $60 \%$ of respondents indicated that the policy would positively affect the quality of education against $26.5 \%$ of respondents that strongly disagree the policy would improve the quality of education. This because the free senior high policy has been given low publicity as $52 \%$ of parents or guardians are unaware of it in the Wa Municipality. The free senior high policy covered all costs related to senior high school but is still seen to be a bit deficient in reducing poverty because it does not include all the students in school, and some of the head teachers are charging illegal fees which are supposed to be covered by the policy. This is shown in the results as, $73 \%$ agreed it does not cover all students, and more than $10 \%$ of parents admitted they have paid for their children's education under the free senior high policy.

The free senior high policy has helped needy families to enroll their children in school and hence reducing financial pressures on parents since they do not pay anything. It goes in line with the results of earlier studies carried out by (Acheampong, 2009; Deininger, 2003; Janus et al., 2007; Joseph, Laura, Peter \& Jonathan, 2000; Olwande et al. 2010; Raymond O., 2012; Tadono \& Smith, 2006; Thomas, 2007; Willms, 2007).

We can justifiably state that the progressive free senior high policy was a good policy but the free senior high policy would be better in solving the high rate of the poverty problem in the Wa Municipality. Parents paid nothing for their children who enrolled to senior high during the 2017/2018-year group aside from the illegal fees charged by some head teachers and the fees some still paid for their children in senior high level 2 and level 3. This free senior high policy if well managed would lead to a drastic reduction of poverty in the Wa Municipality and the whole nation at large. The study has some recommendations based on the challenges identified by the free senior high policy, and these recommendations are detailed later in this paper.

\section{CONCLUSION}

The free senior high policy proved to put more butts on seats in helping to reduce financial burdens on parents than the pre-existing progressive free policy since nothing is supposed to be paid by parents or guardians and this would lead to a drastic reduction of poverty in the Wa Municipality. For the Free senior high policy to completely cut down poverty, the government must ensure that it would always be 'just as it says on the tin.' Free should not be pseudo-free.

\section{RECOMMENDATIONS}

There are some recommendations based on the outcome of the study.

First and foremost, the government should ensure there is a reliable source of funding for schools such as the endowment fund which is proven to be sustainable in developed nations like Germany, ASIA, US, UK among others.

Also, funding to schools should be disturbed in time, and there must be a regular assessment of the free senior high program to maintain and improve the quality of senior high education.

Additionally, the government must ensure that all the citizens are informed about the free high senior high policy through the media and other available channels.

Furthermore, the government must provide adequate infrastructure such as classrooms, dormitories to accommodate students and teachers must be motivated to ensure the quality of education.

Finally, head teachers must be cautioned in regards to charging any illegal fees at the senior high level, and those who do so must be sanctioned.

\section{REFERENCES}

Akyeampong, K. (2009). Revisiting free compulsory universal basic education (FCUBE) in Ghana. Comparative Education, 45 (2), 175-195.

African Development Fund (2003). Republic of Ghana development of senior secondary education project (education iii) appraisal report.

Boatman A., \& Long B. T. (2016). Does financial aid impact college student engagement? Evidence from the Gates Millennium Scholars Program.

Deininger, K. (2003). Does Cost of Schooling Affect Enrollment by the Poor? Universal Primary Education in Uganda. Economics of Education Review, 22, 291-305).

Denny, k., Doyle, O., McMullin, \& Sullivan V. (2014). Money, mentoring and making friends: The impact of a multidimensional access program on student performance. Economics of Education Review.

Dynarski S., \& Scott-Clayton J. (2013). Financial aid policy: Lessons from research. In L Barrow, T Brock \& C Rouse (eds). Postsecondary education in the United States. Princeton, NJ. The Future of Children, 23(1): 67-9.

Florence M. Itegi. (2016). Financing Secondary Education in Kenya: Exploring Strategic Management Approach for Improving Quality of Education. Universal Journal of Educational Research, 4(5), 949-955. https://doi. org/10.13189/ujer.2016.040503

Garcia-Penalosa, C. \& Walde, K. (2000). Efficiency and equity effects of subsidies to higher education. Oxford Economic Papers, 52(4), 702-722.

Garlick R., (2013). How price sensitive is Primary and Secondary School Enrollment? Evidence from Nationwide Tuition Fee Reforms in South Africa.

Ghana Statistical Service (2007). Retrieved from http://www. statsghana.gov.gh/nada/index.php/citations/6

Hammersley, M. (2013) What is qualitative research? London/New York, Bloomsbury. 
Husain, I. (2008). Public policy and social sciences. Lahore: Government College University.

Janus M, Walsh C, Viverios H, Duku E, \& Offord D. (2007). School readiness to learn and neighborhood characteristics. Retrieved from http://offordcentre.com/readiness/ files/PUB.2.2003_Janus-Walsh.pdf $>$ (Version current at September 10, 2007)

Joseph, E. S., Laura, D. T., Peter R. O., \& Jonathan M.O. (2000). The impact of paying for college on family finances.

Meneses F., \& Blanco C. (2010). Financial aid and higher education enrollment in Chile: A government policy analysis.

Melguizo TS 2011. The association between financial aid availability and the college dropout rates in Colombia. https://doi.org/10.1007/s10734-010-9385-8, 231-247.

Moussa, P. B., Gajigo, O., \& Pugatch T. (2015). Financial constraints and girls' secondary education: Evidence from school fee elimination in The Gambia.

MOE. (2015). Ministry of education sector performance report.

MOE. (2016). Ministry of education sector performance report.

MOE. (2017). Republic of Ghana ministry of education sector performance report.

MOESS. (2005). Ministry of Education, Science, and Sports, Ghana. 2005. "Linking ESP and the White Paper Reform”, November 2005.

Natasha, M. G., \& Michelle, M. (2011). The Relationship between scholarships and student success: An art and design case study.

Olwande J., Muyanga M., Mueni E., \& Wambugu S. (2010). Free Primary Education in Kenya: An Impact Evaluation Using Propensity Score Methods. PMMA Working Paper 2010-08

Pettinger, T. (2012). Subsidies for positive externalities, economics. London: Oxford University Press

Obeng R. (2012). The Capitation Grant Policy in Ghana. Retrieved from https://www.ghanaweb.com/GhanaHomePage/News Archive/The-Capitation-Grant-Policy-In-Ghana-259538

Saavedra, J. (2002). Education financing in developing countries: Level and sources of funds. The imperativeness of deregulating government control. Lagos: NAEAP Publication,

Stainton-Rogers (2006) 'Logics of Enquiry' in Potter, S. (ed.) Doing Postgraduate Research (2nd edn), Milton Keynes, The Open University.
Stater, M. (2009). The Impact of financial aid on college GPA at three flagship public institutions. American Educational Research Journal, 46 (3): 782-815.

Tatiana M., Fabio S.T. \& Tatiana V. (2016). Credit for low-income students and access to academic performance in higher education in Colombia: A regression discontinuity approach. World Development, 80, 61-77.

Taryn \& Claudia M. (2012). Investing in schooling in Chile: the role of information

Todaro, \& Smith (2006). Poverty and inequality: concepts, measurement and trends Retrieved from http://siteresources.worldbank.org/INTPOVERTY/Resources/ WDR/overview.pdf

Thomas EM. Readiness to learn at school among five-yearold children in Canada. <http://www.statcan.ca/english/ research/89-599-MIE/89-599-MIE2006004.pdf $>$ (Version current at September 10, 2007)

UNESCO. (2000). World education report. Paris: UNESCO.

UNESCO. (2013). Education for All Global Monitoring Report, (January), 1-11.

UNESCO. (2016). Leaving no, one behind: How far on the way to universal primary and secondary education? 2030, 1-16.

Willms D. (2007). Learning divides: Ten policy questions about the performance and equity of schools and schooling systems. Retrieved from http://www.uis.unesco.org/ template/pdf/EducGeneral/WP5LearningDivides.pdf> (Version current at September 10, 2007).

World Bank. (2005). Expanding opportunities and building competencies for young people: A new agenda for secondary education. Washington: World Bank Publications.

World Bank. (2011). The World Bank annual report. Retrieved from worldbank.org/curated/en/445681468030627288/ pdf/539910ESW0Gray00502301100BOX358360B.pdf

World Bank. (2014). The World Bank annual report.

World Bank. (2017). At the Crossroads: Choices for Secondary Education and Training in Sub-Saharan Africa.

World Bank. (2015). Poverty reeducation in Ghana: progress and challenges. Retrieved from http:/www.worldbank.org/en/country/ghana/publication/poverty-reduction-ghana-progress-challenges

Zoula Lor, 2015. Students speak up on impact of financial aid. Retrieved from https://www.mnprivatecolleges.org/ newsletter/april-2015-newsletter/students-speak-impact-financial-aid 